\title{
SUGAR AND ORGANIC ACID CONTENT OF TOMATO FRUITS (LYCOPERSICON LYCOPERSICUM MILL.) GROWN ON AEROPONICS AT DIFFERENT PLANT DENSITY
}

\author{
J. OSVALD, N. PETROVIČ and J. DeMšAR \\ Institute for Fruit Growing, Viticulture and Vegetable Growing, Agronomy Department, \\ Biotechnical Faculty, SI-1111 Ljubljana, Jamnikarjeva 101. Slovenija \\ (Received: 16 March 2000; accepted: 18 September 2000)
}

\begin{abstract}
The quality of tomato fruits (Lycopersicon lycopersicum Mill.) depends on factors such as production conditions, the chosen cultivar, fertilisation, plant density, etc. The quality of tomato fruits cv. 'Arletta' grown on aeroponics has been analysed. The influence of plant density and pruning on yield quantity and quality was measured. Quality components were determined by high performance liquid chromatography (HPLC). The contents of sugars (sucrose, glucose, fructose and xylose) and organic acids (citric, malic, shikimic and fumaric acid) were analysed separately with regard to different plant density $-12,16,20$ and 24 plants $\mathrm{m}^{-2}$ production surface. Evaluations showed that the differences in tomato quality, regarding the sugar (sucrose $0.46 \mathrm{~g} \mathrm{~kg}^{-1}$, glucose $14.31 \mathrm{~g} \mathrm{~kg}^{-1}$, fructose $12.06 \mathrm{~g} \mathrm{~kg}^{-1}$, xylose $0.27 \mathrm{~g} \mathrm{~kg}^{-1}$ ) and acid content (citric $7.79 \mathrm{~g} \mathrm{~kg}^{-1}$, malic $0.68 \mathrm{~g} \mathrm{~kg}^{-1}$, shikimic $4.36 \mathrm{~g} \mathrm{~kg}^{-1}$, fumaric $14.34 \mathrm{~g} \mathrm{~kg}^{-1}$ ) are not significant statistically with regard to plant density.
\end{abstract}

Keywords: tomato (Lycopersicon lycopersicum Mill.), quality, sugars, organic acid, aeroponics, plant density

Tomato as a vegetable variety is a food greatly appreciated by consumers throughout the year. The yield quality is closely correlated with growing conditions, chosen cultivars, plant care, production techniques, fruits' light exposure, etc. Horticultural market demands 'global quality' (BATTISEL \& ENZO, 1999) both in the commercial (colour, durability, homogeneity, etc.) and in the alimentary aspect (taste, aroma, etc.). These qualities can be attained by proper growing substrates and with planned fertilisation. Tomato fruits produced by these measures are more tasty, evensized, compact, resistant to damage and have a higher sugar content (BATTISEL \& ENZO, 1999).

It has been established that the selection of production techniques is in direct correlation with yield quality (JANSE, 1994); the taste of the yield is dependent on the electric conductivity value (EC) and on the $\mathrm{K}^{+}$to $\mathrm{Ca}^{2+}$ ratio as well as the $\mathrm{Na}^{+}$to $\mathrm{Ca}^{2+}$ ratio. An insufficient supply of $\mathrm{K}^{+}$has the consequence of reducing the acid content, 
and the tomato fruits acquire the characteristic aftertaste (JANSE, 1994). The high content of $\mathrm{Ca}^{2+}$ in the soil or in nutrient solution has a negative influence on fruit quality, because it increases the flouriness (JANSE, 1994). Phosphates and chlorides together with $\mathrm{Ca}^{2+}$ (at higher concentrations) also have a negative influence on the aroma features (JANSE, 1994). Greater concentrations of nutrient solution (higher ECvalue) increase the tomato market value (the fruits are more juicy and aromatic and they contain higher amounts of sugars and acids (JANSE, 1994; SIRIGU et al., 1999)).

Higher concentrations of nutrient solution increase the osmotic pressure too and this way lower the consumption of nutrient solution (SIRIGU et al., 1999). This leads to signs of water stress (reduction of vegetative development, reduction of water content in plant tissue, increase of sugar and acid concentration as well as dry substance in the fruit juice). The nutrient solution concentration and its osmosis have a far greater influence on fruit quality than nutrient solution compound has. JANSE (1994) noted that by increasing the EC-value for $1 \mathrm{mS} \mathrm{cm}^{-1}$ content of sugars and acids increases by $4 \%$.

The quality of tomatoes produced in protected areas (after SIRIGU et al., 1999) are appreciated by consumers (coloration and fruit shape, fruit size, increased content of sugars and acids) and is accepted on the Central European market. In traditional cultivation, these quality improvements are obtained by increased fertilisation and reduced watering.

\section{Materials and methods}

The research of plant density influence on the quality of tomatoes grown in aeroponics was done in a protected area - a greenhouse with double plastic coverings.

Aerponics is one of the soilless culture systems, where the plant roots are hanging in closed chambers. Periodically roots are sprayed with recycled nutrient solution.

The aeroponic system used in this trial was A-frame type, triangular in shape with equal sides of $1 \mathrm{~m}$. The system was $15 \mathrm{~m}$ long, covering $15 \mathrm{~m}^{2}$ of floor surface and having $30 \mathrm{~m}^{2}$ of production area. Seedlings of tomato cultivar 'Arletta $\mathrm{F} 1$ ' were repotted into plastic net-pots with a diameter of $5.5 \mathrm{~cm}(02.05 .1999)$. In the phase of developing the second pair of leaves, the plants were positioned (planted) in the holes of styrofoam plates on the system (24.05.1999). The seedlings were fertiirigated with a nutrient solution of higher concentration (EC 4-5 $\mathrm{mS} \mathrm{cm}^{-1}$ ).

The plants were planted in four different plant densities: A ( 24 plants $\left.\mathrm{m}^{-2}\right), \mathrm{B}(32$ plants $\left.\mathrm{m}^{-2}\right), \mathrm{C}\left(40\right.$ plants $\left.\mathrm{m}^{-2}\right)$ and $\mathrm{D}\left(48\right.$ plants $\left.\mathrm{m}^{-2}\right)$ in three repetitions for each density. The trials were located in the 'Pilot farm' of the Biotechnical Faculty in Ljubljana. 
The tomato plant roots were supplied with nutrient solution (Table 1) by fine sprinklers in programmed intervals of $5 \mathrm{~min}$, and $60 \mathrm{~s}$ duration time of sprinkling. During the trial, the quality of nutrient solution was observed daily, its concentration was measured with a conductometer and kept at $3.5 \mathrm{mS} \mathrm{cm}^{-1}$. The acidity of the nutrient solution was also measured daily and balanced in the range of $\mathrm{pH} 5.5$ to 6.0 by the addition of sulphurous acid. If required the composition of the nutrient solution was corrected or replaced with a new stock (regarding the plant growth and temperature).

The plants were pruned regularly and cut back just under the second flower branch, leaving three leaves upwards from the first flower branch (29. 06.1999).

If required, the fruit branches were pruned leaving four fruits on each branch. Harvest was performed on all production area simultaneously (12. 08. 1999).

Estimation of the ripeness, development and quality of tomato fruits were carried out separately for each repetition and location of production area. The yield was determined by weighing the fruits per plant and $\mathrm{m}^{2}$ of production area.

Fresh tomato fruits at technological ripeness were used for samples. The total soluble matter was determined by hand refractometer (Kübler) at standard conditions expressed in \%. For each plant density four measurements have been carried out.

The content of sugars (sucrose, glucose, fructose and xylose) and organic acids (citric, malic, shikimic and fumaric acid) was analysed separately by high performance liquid chromatography (HPLC) at the Biotechnical Faculty, Institute for Fruit Growing, Viticulture and Vegetable Growing in Ljubljana (Table 2).

The HPLC system consisted of Thermo Separation Products (TSP) equipment with a pump model P2000, autosampler model AS1000, column heater and OS/2 Warp IBM Operating system (1994)-work station. The method was fully described by DOLENC-ŠTURM and co-workers (1999).

Table 1

List of salts required for preparation of 100.000 litres of nutrient solution

\begin{tabular}{lrll}
\hline Salt - macroelements & $(\mathrm{kg})$ & Salt-microelements & $(\mathrm{kg})$ \\
\hline $\mathrm{KNO}_{3}$ & 42.0 & $\mathrm{HEDTA}(\mathrm{Fe} \mathrm{12 \%})$ & 0.7 \\
$\mathrm{NH}_{4} \mathrm{NO}_{3}$ & 4.0 & $\mathrm{H}_{3} \mathrm{BO}_{3}$ & 0.24 \\
$\mathrm{~K}_{2} \mathrm{SO}_{4}$ & 31.4 & $\mathrm{MnSO}_{4}$ & 0.17 \\
$\mathrm{KH}_{2} \mathrm{PO}_{4}$ & 20.4 & $\mathrm{ZnSO}_{4}$ & 0.142 \\
$\mathrm{MgSO}_{4} \times 7 \mathrm{H}_{2} \mathrm{O}$ & 43.0 & $\mathrm{CuSO}_{4}$ & 0.019 \\
$\mathrm{Ca}\left(\mathrm{NO}_{3}\right)_{2} \times 4 \mathrm{H}_{2} \mathrm{O}$ & 92.5 & $\mathrm{MoCl}_{3}$ & 0.012 \\
\hline
\end{tabular}


Table 2

HPLC conditions for analysing sugars and organic acids

\begin{tabular}{lll}
\hline HPLC conditions & Sugar analyses & Organic acid analyses \\
\hline Cartridge & Aminex HPX-87C & Aminex HPX-87C \\
Sample & $20 \mu \mathrm{l}$ & $20 \mu \mathrm{l}$ \\
Eluent & bidistilled water & $4 \mathrm{mM} \mathrm{H} \mathrm{SO}_{4}$ \\
Flow rate & $0.6 \mathrm{ml} \mathrm{min}{ }^{-1}$ & $0.6 \mathrm{ml} / \mathrm{min}$ \\
Temperature & $85^{\circ} \mathrm{C}$ & $65^{\circ} \mathrm{C}$ \\
Detector & Sephadex RI-71 & WellChrom K - 2500 UV \\
\hline
\end{tabular}

\section{Results}

Results of tomato production cultivar 'Arletta' on aeroponics with different plant density and with cut back are presented in Table 3 .

The average fruit weight at all plant densities was within the limits of not statistically significant differences. Significant differences on an average yield, are from 12.6 to $21.2 \mathrm{~kg} \mathrm{~m}^{-2}$.

Table 4 shows the results of total soluble solids (SS in \%), amount of separated sugars (sucrose, glucose, xylose, fructose) and amount of total sugar.

The amount of total soluble substance is in the range from 4.0 to $4.8 \%$ with no significant differences caused by plant density.

The chromatogram of standard sugar solutions is shown in Fig. 1.

Table 3

Achieved yield of tomato fruits $\mathrm{cv}$. 'Arletta Fl' grown on aeroponics with different plant density (4 types of density - from 24 to 48 plants $\mathrm{m}^{-2}$ ) with decapitation on single branch

\begin{tabular}{ccccc}
\hline $\begin{array}{c}\text { Plant density } \\
\text { Sign }\end{array}$ & No. plants $\mathrm{m}^{-2}$ & $\begin{array}{c}\text { Average yield } \mathrm{m}^{-2} \\
\text { of floor surface }(\mathrm{kg})\end{array}$ & $\begin{array}{c}\text { Average fruit } \\
\text { weight (g) }\end{array}$ & $\begin{array}{c}\text { Average yield } \\
\text { per plant (g) }\end{array}$ \\
\hline A & 24 & 12.6 & 122 & 526 \\
B & 32 & 16.4 & 120 & 513 \\
C & 40 & 17.5 & 125 & 438 \\
D & 48 & 21.2 & 122 & 442 \\
\hline
\end{tabular}


Table 4

Content of total soluble solids (SS) and sugars in tomato fruits grown at different plant densities on aeroponics

\begin{tabular}{lccccccc}
\hline \multirow{2}{*}{$\begin{array}{l}\text { Plant density } \\
\text { Sign }\end{array}$} & No. & SS & \multicolumn{5}{c}{ Average content of sugars in $\mathrm{g} \mathrm{kg}^{-1}$} \\
\cline { 5 - 8 } & plants $\mathrm{m}^{-2}$ & $(\%)$ & Sucrose & Glucose & Xylose & Fructose & $\Sigma$ \\
\hline A & 24 & 4.1 & 0.35 & 11.68 & 0.42 & 11.32 & 23.77 \\
B & 32 & 4.3 & 0.39 & 11.73 & 0.17 & 11.15 & 23.44 \\
C & 40 & 4.4 & 0.63 & 12.14 & 0.29 & 11.31 & 24.37 \\
D & 48 & 4.2 & 0.49 & 12.95 & 0.22 & 14.46 & 28.13 \\
Average & & 4.2 & 0.46 & 12.12 & 0.27 & 12.06 & 24.91 \\
Min. & & 4.0 & 0.22 & 9.89 & 0.10 & 9.22 & 20.61 \\
Max. & & 4.8 & 1.21 & 13.80 & 0.68 & 17.68 & 31.78 \\
LSD 0.05 & & & 0.34 & 2.26 & 0.42 & 3.32 & \\
\hline
\end{tabular}

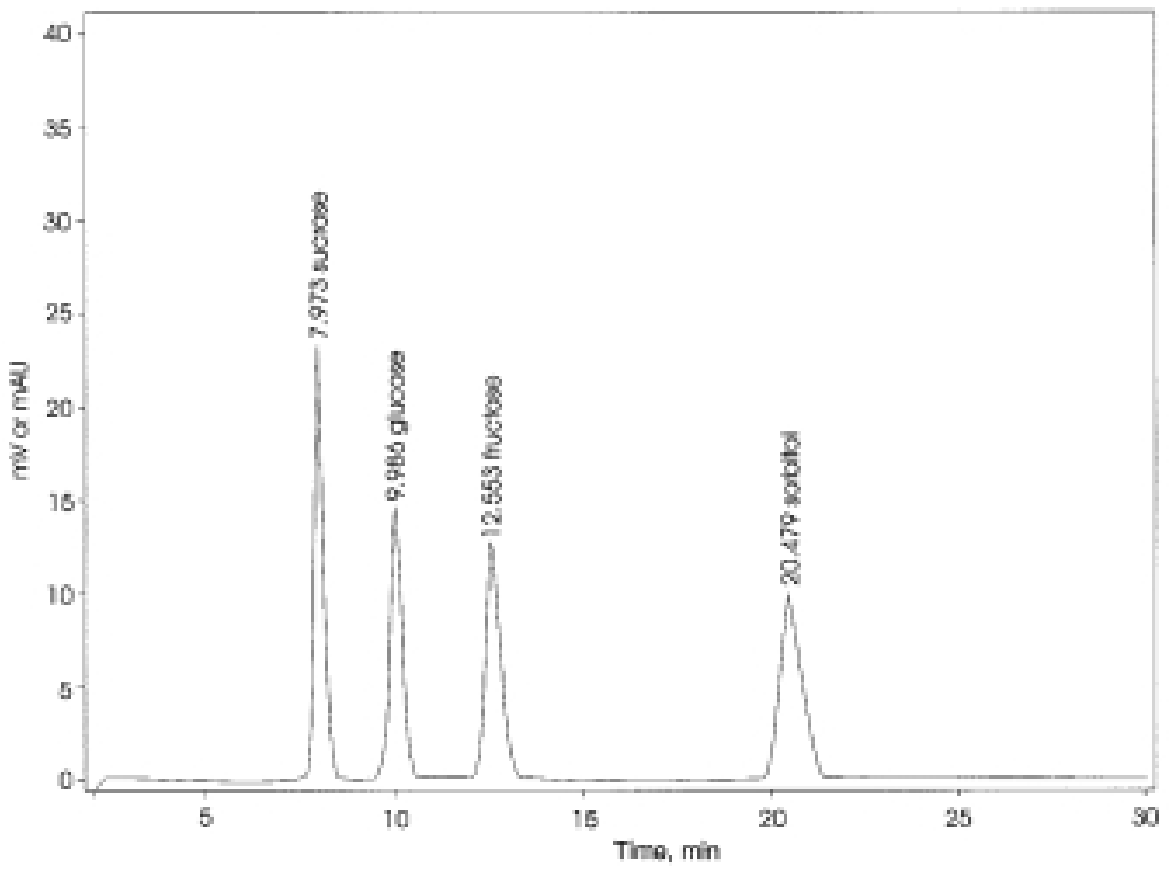

Fig. 1. Chromatographic separation of sugars in tomato fruits 
Also, there are no significant differences in content of the sugars. The measured values of sucrose are in the range from 0.35 to $0.63 \mathrm{~g} \mathrm{~kg}^{-1}$, glucose from 11.68 to $12.95 \mathrm{~g} \mathrm{~kg}^{-1}$, xylose from 0.17 to $0.42 \mathrm{~g} \mathrm{~kg}^{-1}$ and fructose from 11.15 to $14.46 \mathrm{~g} \mathrm{~kg}^{-1}$. The amount of total sugars is from 23.44 to $28.13 \mathrm{~g} \mathrm{~kg}^{-1}$. The average amount of total sugars is $24.91 \mathrm{~g} \mathrm{~kg}^{-1}$, significant decrease was noted at plant density of 48 plants $\mathrm{m}^{-2}$ of floor surface.

Changes in the organic acid content (citric, malic, shikimic, fumaric) as a function of plant density are shown in Table 5 .

The chromatogram of standard organic acid solutions is shown in Fig. 2.

Significant differences in the average amount of organic acids were not found as a function of plant density. The highest values were measured for citric acid, ranging from 7.27 to $8.35 \mathrm{~g} \mathrm{~kg}^{-1}$, malic acid from 0.60 to $0.74 \mathrm{~g} \mathrm{~kg}^{-1}$, shikimic acid from 3.94 to $4.70 \mathrm{mg} \mathrm{kg}^{-1}$ and fumaric acid 13.67 to $15.51 \mathrm{mg} \mathrm{kg}^{-1}$.

At the lowest plant density, content of citric acid was the highest $\left(8.35 \mathrm{~g} \mathrm{~kg}^{-1}\right)$, while at the highest plant density the content of citric acid was the lowest $\left(7.27 \mathrm{~g} \mathrm{~kg}^{-1}\right)$. In case of fumaric acid the opposite effect has been observed.

Table 5

Content of organic acids in tomato fruits grown at different plant densities on aeroponics

\begin{tabular}{|c|c|c|c|c|c|}
\hline \multirow{2}{*}{$\begin{array}{c}\text { Plant density } \\
\text { Sign }\end{array}$} & \multirow{2}{*}{$\begin{array}{l}\text { No. } \\
\text { plants } \mathrm{m}^{-2}\end{array}$} & \multicolumn{4}{|c|}{ Average content of organic acids } \\
\hline & & $\begin{array}{c}\text { Citric } \\
\left(\mathrm{g} \mathrm{kg}^{-1}\right)\end{array}$ & $\begin{array}{c}\text { Malic } \\
\left(\mathrm{g} \mathrm{kg}^{-1}\right)\end{array}$ & $\begin{array}{l}\text { Shikimic } \\
\left(\mathrm{mg} \mathrm{kg}^{-1}\right)\end{array}$ & $\begin{array}{l}\text { Fumaric } \\
\left(\mathrm{mg} \mathrm{kg}^{-1}\right)\end{array}$ \\
\hline A & 24 & 8.35 & 0.74 & 4.57 & 13.78 \\
\hline B & 32 & 7.56 & 0.60 & 4.24 & 13.67 \\
\hline $\mathrm{C}$ & 40 & 7.97 & 0.72 & 4.70 & 15.51 \\
\hline $\mathrm{D}$ & 48 & 7.27 & 0.64 & 3.94 & 14.38 \\
\hline Average & & 7.77 & 0.68 & 4.36 & 14.33 \\
\hline Min. & & 7.15 & 0.46 & 3.61 & 7.81 \\
\hline Max. & & 8.59 & 0.89 & 5.28 & 19.32 \\
\hline LSD 0.05 & & 1.11 & 0.17 & 1.20 & 5.78 \\
\hline
\end{tabular}




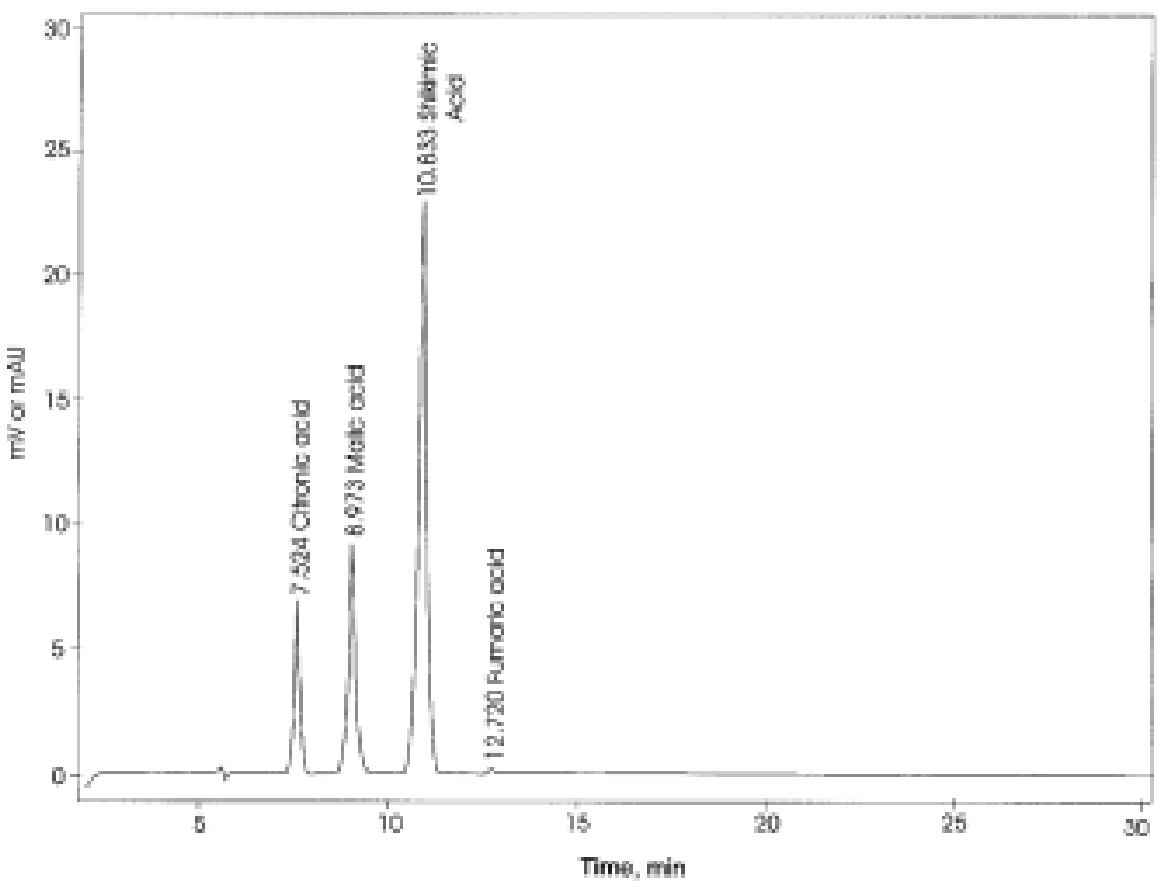

Fig. 2. Chromatographic separation of organic acids in tomato fruits

Table 6

The content of soluble solids (SS), total sugars $\left(\mathrm{g} \mathrm{kg}^{-1}\right)$, glucose/fructose, total sugars/citric acid and citric/malic acid ratio in tomato fruits

\begin{tabular}{lccccc}
\hline $\begin{array}{c}\text { Plant density } \\
\text { Sign }\end{array}$ & $\begin{array}{c}\text { Soluble solids } \\
\text { SS (\%) }\end{array}$ & $\begin{array}{c}\text { Total sugars } \\
\left(\mathrm{g} \mathrm{kg}^{-1}\right)\end{array}$ & $\begin{array}{c}\text { Glucose/ } \\
\text { fructose (ratio) }\end{array}$ & $\begin{array}{c}\text { Total sugars/ } \\
\text { citric acid (ratio) }\end{array}$ & $\begin{array}{c}\text { Citric/malic } \\
\text { acid (ratio) }\end{array}$ \\
\hline A & 4.1 & 23.77 & 1.03 & 2.85 & 11.28 \\
B & 4.3 & 23.44 & 1.05 & 3.10 & 12.60 \\
C & 4.4 & 24.37 & 1.07 & 3.06 & 11.07 \\
D & 4.2 & 28.13 & 0.89 & 3.87 & 11.36 \\
Average & 4.25 & 24.91 & 1.00 & 3.20 & 11.36 \\
Recommended value & $4.8-6.6$ & $24.3-52$ & $0.7-0.95$ & $1.87-7.65$ & $2.96-6.5$ \\
Min. & 4.1 & 10.61 & 0.74 & 2.34 & 13.57 \\
Max. & 4.8 & 31.78 & 1.13 & 4.85 & 9.38 \\
\hline
\end{tabular}

Table 6 shows the values of sugars and acids in reciprocal ratios. 
The measured average values between glucose and fructose are in a ratio from 0.89 to 1.07 ; sucrose and xylose from 0.83 to 2.29 ; total sugars and citric acid 2.85 to 3.87 and citric acid to malic acid from 11.07 to 12.60 .

From the results of HPLC analysis and ratios of separated substances, it is noticeable that at the highest plant density (D) the total sugars as well as the ratio of sugar/acid are at the highest level.

\section{Discussion}

Quality is an important factor in the production and marketing. It is often strictly correlated with production circumstances, chosen cultivars, plant care, production techniques, fruits' light exposure, etc. These aims can be achieved by choosing proper growing substrates and by planned fertilisation (JANSE, 1994). By these measures, tomato fruits produced are more tasty, even-sized, compact, resistant to damage and posses higher sugar content (BATTISTEL \& ENZO, 1999). The quality of tomato fruits depends on various factors, but the greatest impact is caused by sugars and organic acids (SHARMA \& SHARMA, 1990; DOLENC-ŠTURM et al., 1999), as was detected in this research as well.

Quality, to a great extent, depends on the total sugar amount $\left(24.91 \mathrm{~g} \mathrm{~kg}^{-1}\right)$, total soluble solids (4.15\%), optimal glucose/fructose ratio (1.00), citric to malic ratio (11.36) and ratio between total sugar content and citric acid (3.2). These results imply that by increasing the concentration of the nutrient solution an impact can be achieved on the increase of sugar and organic acid content in tomato fruits, which leads to improved taste and quality.

Some authors assume (BATTISTEL \& ENZO, 1999) that tomato quality is significantly affected by climatic circumstances, and less by the chosen production techniques. For quality improvement it is advisable to use proper cultivars (e.g. Mediterranean origin), that ripe simultaneously, posses intensive red colour and have high sugar content, etc. (BATTISTEL \& ENZO, 1999).

In hydroponic tomato production, due to the small amount of substrate or its absence, regular and frequent nutrient solution supply is needed to prevent stresses and the consequent quality reduction (SIRIGU et al., 1999). With proper and regular nutrient solution supply towards plant roots, it is possible to achieve the planned tomato fruit quantity and quality with optimal sugar/acid ratio, as shown in Table 6. 


\section{Conclusions}

The results of aeroponic tomato production combined with cut back and increased plant density are promising. In a short time high yields and marketable quality could be achieved by this method.

Yield analysis has proved that increased plant density per $\mathrm{m}^{2}$ does not decrease the average fruit weight, while the total yield is increased.

HPLC sugar analysis of ripened fruits proved that sugar measures at different plant densities and locations do not show significant differences with regard to the average sugar content. Similar results were found considering the four most common organic acids in tomato fruits.

It would be advisable to measure the content of sugars and organic acids for the same cultivar but at different production systems and circumstances with various degrees of nutrient supply and simulations of water and nutrient stress.

\section{References}

BATTISEL, P. \& ENZO, M. (1999): La coltura fuori suolo del pomodoro da mensa in Italia. L'Informatore Agrario, 6, 43-51.

DOLENC-ŠTURM, K., ŠTAMPAR, F. \& USENIK, V. (1999): Evaluating of same quality parameters of different apricot cultivars using HPLC method. Acta Alimentaria, 28, 297-309.

JANSE, J. (1994): Besserer Geschmack bei Tomaten. Die Zusammensetzung der Nährlösung hat einen Einfluss. Gemüse, 7, 390-391.

SHARMA, S. R. \& SHARMA, S. D. (1990): Studies on the physico-chemical changes during fruit development of same cultivars of apricot (Prunus armeniaca L.). Haryana J. Hort. Sci., 19, 33-38.

SIRIGU, A., LEONI, S., PISANU, A. B. \& GRUDINA, R. (1999): Concentrazione salina e caratteristiche qualitative del pomodoro Camone. L'Informatore Agrario, 6, 55-58. 